УдК 616-002.36+616.27-002]-089:612.017.1

DOI 10.11603/2414-4533.2017.1.6731

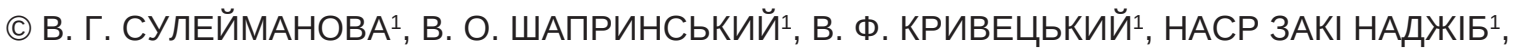
Т. А. ХМЕЛЕВСЬКА 2

Вінницький національний медичний університет ім. М. І. Пирогова ${ }^{1}$

Вінницька обласна клінічна лікарня ім. М. І. Пирогова²

\title{
.Лікування гнильної флегмони шиї, ускладненої медіастинітом, у хворого з гіпоергічною імунною відповіддю
}

\begin{abstract}
Мета роботи: описати правильний метод лікування пацієнтів із гнильною флегмоною шиї, ускладненою медіастинітом, на прикладі випадку успішного лікування хворого з ускладненим шийним некротизуючим фасціїтом та гіпоергічною імунною відповіддю.

Гнильна флегмона шиї, ускладнена медіастинітом, - досить рідкісне захворювання з високим рівнем летальності (40-85 \%). У статті представлено випадок успішного лікування хворого з ускладненим шийним некротизуючим фасціїтом та гіпоергічною імунною відповіддю на фоні ревматоїдного артриту, тривалий час лікованого глюкокортикостероїдами. Раннє хірургічне втручання з максимально широким розкриттям і наскрізним дренуванням всіх уражених клітковинних просторів 3 адекватною антибактеріальною терапією є єдиним правильним методом лікування таких пацієнтів.
\end{abstract}

Ключові слова: гнильна флегмона шиї; медіастиніт; цервікотомія.

Гнильна інфекція - це некротизуюча інфекція м’яких тканин (“Necrotizing soft tissue infections” або "Necrotizing fasciitis" в англомовній літератуpi, вперше названа так Wilson у 1952 р.), яка рідко зустрічається, важка для діагностики, швидко прогресує і асоціюється з високою смертністю [1]. Причиною гнильної інфекції $є$ неклостридіальні анаероби, але частіше це полімікробні асоціації з аеро- та анаеробів, які виявляють синергізм у іï̈ поширенні [2]. За даними Andrew J. Thomas (2012), у США за рік реєструють від 500 до 1500 випадків "Necrotizing soft tissue infections", серед яких шийний некротизуючий фасціїт, становлячи лише $5 \%$, характеризується високою летальністю - до 40 \% [3]. У вітчизняних джерелах смертність коливається від 30 до 85 \% [4]. При гнильнонекротичній флегмоні шиї відзначається швидке поширення запалення на сусідні тканини з переважанням загальних проявів захворювання над місцевими. Некроз швидко уражає підшкірний жир, м'язи і фасції. Локально виявляють болючий щільний інфільтрат без чітких меж, яскравої гіперемії і флуктуації. Іноді пальпаторно визначають крепітацію (продукт життєдіяльності анаеробів). Клітковинні простори стають брудно-сірого кольору, рановий вміст незначний, брудного бурого кольору, може бути з геморагічним включенням і специфічним запахом [5]. Без своєчасного активного хірургічного лікування швидко виникають поліорганна недостатність і сепсис, а некроз швидко поширюється в напрямку середостіння, що і призводить до летального наслідку [6, 7]. Наводимо власне спостереження лікування хворо- го з ускладненим шийним некротизуючим фасціїтом та гіпоергічною імунною відповіддю на фоні ревматоїдного артриту, тривалий час лікованого глюкокортикостероїдами. У доступній літературі ми не знайшли повідомлень про випадки лікування таких пацієнтів з даною супутньою гормонозалежною патологією, що обгрунтовує доцільність публікації.

Клінічний випадок. Хворий Д., 61 рік, № історії хвороби 4771, госпіталізований в клініку хірургії № 1 05.03.2015 р. На момент прийняття скаржився на загальну слабість, виражену дисфагію, обмежене відкривання рота, обмежені рухи шиєю, біль у ділянці шиї, більше справа, запаморочення, задишку, набряк нижньої третини обличчя, шиї. 3 анамнезу захворювання відомо, що хворіє він з 28.02.15 р., коли почав турбувати зруйнований зуб на нижній щелепі справа, який було видалено в ЦРЛ за місцем проживання, але в післяопераційному періоді наріс набряк і з'явилася субфебрильна температура, тому був направлений в обласну лікарню. 3 анамнезу життя відомо, що він хворіє на ревматоїдний поліартрит протягом 5 років, з приводу чого приймає метилпреднізолон 40 мг/д; спостерігається ревматологом. Окрім цього, відзначає медикаментозну алергію на антибіотики групи фторхінолонів.

На момент об'єктивного обстеження загальний стан тяжкий, шкіра бліда, температура тіла $37,2{ }^{\circ} \mathrm{C}$. Над легенями - жорстке дихання, поодинокі вологі базальні хрипи, пульс - 90 уд/хв, середніх властивостей, АТ=100/60 мм рт. ст. Рухи в суглобах утруднені як наслідок ревматоїдно- 
го поліартриту. Для визначення ступеня тяжкості загального стану пацієнта був використаний інтегральний показник Морозової М. М., 2014 р. [8]. У хворого він дорівнював 46, що відповідало тяжкому або вкрай тяжкому стану.

Локальний статус: асиметрія обличчя за рахунок набряку підщелепних, більше справа, та підборідної ділянок, передньої поверхні шиї до яремної вирізки. Гіперемія із синюшним відтінком ураженої ділянки слабковиражена, там же визначається щільний, помірно болючий інфільтрат. Зміщення гортаноглотки посилює біль. Відкривання рота обмежене до 2 см через виражений тризм жувальних м'язів. Голос хриплий, артикуляція також утруднена і болюча. Постукування по руків’ю груднини безболісне.

Зміни в лабораторних показниках на 05.03.15 р. загальний аналіз крові: зсув лейкоцитарної формули вліво (п/я - 24 \%) і прискорення ШОЕ - 58 мм/год; загальний аналіз сечі: протеїнурія (білок - 0,33 г/л) і циліндрурія (циліндри зернисті - 0-1 в п/3). Біохімічні аналізи крові: підвищений рівень сечовини 14,1 мМоль/л і креатиніну - 181 мкМоль/л. Коагулограма: фібриноген В - 11,1 г/л.

На оглядовій рентгенограмі ОГК 05.03.15 р.: втрата чіткості контуру і розширення верхнього середостіння по правому краю як ознаки верхнього медіастиніту. Оглядові рентгенограми шиї в двох проекціях (прямій і правій боковій) за Земцовим: потовщення і набряк м'яких тканин перед глоткою і трахеєю із включеннями прошарків газу всередині як ознаки глибокої флегмони шиї.

У відділенні хворий консультований суміжними спеціалістами (щелепно-лицьовий хірург, оториноларинголог, терапевт), після чого був встановлений попередній діагноз: “Одонтогенна глибока флегмона дна порожнини рота і шиї, ускладнена верхнім переднім медіастинітом. Ішемічна хвороба серця. Атеросклеротичний міокардіосклероз, аортосклероз, коронаросклероз з інфекційно-алергічним міокардитом. СН I-IIA. Ревматоїдний артрит, поліартрит”.

Хворий після нетривалої інфузійної підтримки та консультації анестезіолога в ургентному порядку був взятий в операційну. Інтубацію трахеї проведено за допомогою фібробронхоскопа на операційному столі, для знеболювання застосовано комбінований внутрішньовенний наркоз із міорелаксацією та ШВЛ. Флегмону дна порожнини рота розкрито двома підщелепними розрізами до 3 см від кута нижньої щелепи і паралельно їй та підборідним розрізом (1,5 см) по серединній лінії шиї. Спарені дренажні трубки проведено наскрізь через підщелепні і виведено через підбо- рідний розріз. Превісцеральна флегмона розкрита правим та лівим доступами по передніх краях кивальних м'язів і також дренована претрахеально наскрізь двома трубчастими дренажами через дані цервікотомії. М'які тканини, включаючи фасції, набряклі, з некротично зміненими сірими ділянками, просякнуті брудним іхорозним ексудатом у малій кількості із включеннями бульбашок повітря із різким неприємним запахом. Проведено некректомію. При подальшій ревізії виявлено поширення гнильно-некротичного процесу в переднє верхнє середостіння до кута Людовіка. Виконано шийну медіастинотомію до 2 см над яремною вирізкою і проведено сліпе дренування передньоверхнього середостіння двома трубчастими стандартними дренажами. Інтраопераційної кровотечі, пошкодження вісцеральних органів не було.

Ранній післяопераційний період тривав у відділенні інтенсивної терапії з 05.03.15 до 08.03.15 р., де хворий до 07.03.15 р. перебував на інфузії вазопресорів і дихав самостійно через інтубаційну трубку на інгаляціях кисню. 08.03.15 р. був екстубований і на фоні стабільної гемодинаміки переведений у відділення торакальної хірургії. У відділенні одужання хворого набуло досить млявого затяжного перебігу, післяопераційні рани повільно очищувалися від гнійно-некротичних нашарувань, а грануляції з’являлись досить пізно і були в'ялими та блідими. Перші 3 післяопераційні доби виділення з ран були у досить великій кількості, брудно-геморагічного характеру. Виділень по дренажах після 3-ї доби майже не спостерігали, тому дренажі використовували надалі для санації розчинами антисептиків. У відділенні були продовжені етапні некректомії. Для місцевого лікування ран у першій фазі ранового процесу було застосовано нанорозмірну ранозагоювальну композицію “Метроксан” вітчизняного виробництва. 18.03.15 р. рани почали очищуватись від некрозів, з'явилися перші грануляції. 26.03.15 р. видалено останні трубчасті дренажі, які були частково замінені на гумові випускники. 27.03.15 р. рани очистились від некрозів і почали гранулювати більш активно. Загоєння ран відбувалось за типом вторинного натягу у міру їх очищення. Консервативно хворий отримував дексаметазон з наступною заміною на метилпреднізолон, фуросемід, декскетопрофен, пантопразол, корвітин, диклофенак натрію, еноксапарин, інфузійну терапію кристалоїдами. Курс антибактеріальної терапії був розпочатий метронідазолом з цефоперазоном, захищеним сульбактамом. 13.03.15 р. отримали результат бактеріального посіву гною $з$ рани: синьогнійна паличка, чутлива до іміпенему, меро- 
пенему, амікацину, тобраміцину, піперациліну, азтреонаму, ципрофлоксацину, левофлоксацину і гатифлоксацину (NB! На групу фторхінолонів алергія), відповідно до чого антибактеріальну терапію продовжено з використанням тільки одного іміпенему, захищеного циластатином натрію (карбапенем, який також діє бактерицидно і на групу анаеробів). Наявність анаеробного компонента в даному випадку доведена тільки клінічно і рентгенологічно, оскільки умов для культурування анаеробів у лікарні недостатньо. Ознаками гнильного характеру нагноєння були: щільний набряк підщелепних ділянок і шиї без вираженої гіперемії шкіри та інтенсивного больового синдрому, широке охоплення патологічним процесом клітковинних просторів дна порожнини рота 3 наступним опусканням некротизуючого фасціїту превісцерально на шиї із подальшим прямуванням до верхньо-переднього середостіння, м'які тканини на розрізі тьмяні, набряклі, з сірими, некротично зміненими ділянками, просякнуті брудним бідним іхорозним ексудатом із включеннями бульбашок повітря та різко неприємним запахом. Також у післяопераційному періоді було проведено курс санаційних ФБС і лазеротерапії. На контрольних рентгенограмах шиї та ОГК з 13.03 .15 р. ознак медіастиніту і глибокої флегмони шиї не виявлено. У лабораторних аналізах на момент завершення стаціонарного лікування зберігалися лише протеїнурія (0,264 г/л), підвищення ШОЕ (60 мм/год) і з'явилася анемія II ст. (Нb - 88 г/л). Хворий виписаний зі стаціонару 06.04.15 р. (32 ліжко-дні) у задовільному стані.

Обговорення. У літературі знаходимо лише одиничні спостереження гнильної флегмони шиї, частіше інфікуються черевна стінка, промежина і кінцівки. За даними Shaariyah M. M. et al. (2010), у дослідженні зі 128 хворих із некротизуючим фасціїтом лише у 5 випадках інфекція уразила голову і шию [1]. Десятерик В. І. та співавт., дослідивши 236 хворих із флегмонами шиї, встановили гнильний характер нагноєння лише у 7 пацієнтів, в одного $з$ яких захворювання ускладнилось медіастинітом [5]. На початку хвороби ознаки загальної інтоксикації переважають над місцевими ознаками нагноєння, що значно утруднює діагностичний пошук. Останнім десятиліттям все частіше знахо-

\section{СПИСОК ЛІТЕРАТУРИ}

1. Necrotizing fasciitis of the head and neck: surgical outcomes in three cases / M. M. Shaariyah, M. B. Marina, M. Y. Razif [et al.] // Malaysian Journal of Medical Sciences. - 2010. - Vol. 17. - № 2. - P. 51-55.

2. Microbiological examination and antibiotic sensitivity of infections in the head and neck. Has anything changed? / S. Farmahan, димо повідомлення про те, що поширена гнильна інфекція шиї розвивається саме серед людей похилого чи старечого віку з фоновою патологією (цукровим діабетом, ішемічною хворобою серця, онкозахворюваннями, хронічним алкоголізмом, патологічним ожирінням та ін.), тому імунна відповідь у них недостатньо яскраво виражена [9, 10]. Це призводить до стертої клінічної картини як зі сторони осередку нагноєння, так і з боку загальної реакції організму на запалення. У нашому випадку гнильна поширена одонтогенна глибока флегмона шиї і дна порожнини рота, ускладнена переднім верхнім медіастинітом, виникла у хворого із супутнім ревматоїдним гормонозалежним поліартритом. Пацієнт тривалий час був лікований глюкокортикоїдами, що викликало імунодепресію. Післяопераційний період набув затяжного характеру в плані очищення і загоєння ран, що виявлялося в повільному їх очищенні від некрозів і необхідності етапних некректомій, появі в’ялих грануляцій тільки на 13-ту добу післяопераційного періоду. Такий нетиповий гіпоергічний перебіг захворювання пояснюємо слабкою імунною відповіддю організму на фоні тяжкого аутоімунного захворювання і тривалого приймання глюкокортикоїдів, а також пізнім (через 5 діб після початку захворювання) зверненням за кваліфікованою медичною допомогою. Проте дотримання активної ранньої хірургічної тактики у вигляді широкого розкриття і наскрізного дренування клітковинних просторів шиї та верхнього переднього середостіння, настороженість у плані гнильної етіології захворювання і правильної тактики ведення післяопераційного періоду дозволили уникнути подальших ускладнень і врятувати життя пацієнту.

Висновки. 1. У хворих з супутньою фоновою патологією рання своєчасна діагностика шийного некротизуючого фасціїту досить утруднена через гіпоергічну імунну відповідь організму, тому процес одужання набуває затяжного млявого перебігу, особливо при поширенні інфекції в напрямку середостіння.

2. Раннє хірургічне втручання з максимально широким розкриттям і наскрізним дренуванням всіх уражених клітковинних просторів із адекватною антибактеріальною терапією є єдиним правильним методом лікування таких пацієнтів.

D. Tuopar, P. J. Ameerally [et al.] // British Journal of Oral and Maxillofacial Surgery. - 2014. - Vol. 52. - № 7. - P. 632-635.

3. Thomas A. J. Retrospective evaluation of laboratory-based diagnostic tools for cervical necrotising fasciitis / A. J. Thomas, T. K. Meyer // The Laryngoscope. - 2012. - № 122. - P. 26832687. 


\title{
ПОВІДОМЛЕННЯ
}

4. Случай успешного лечения одонтогенной гнилостной флегмоны шеи, осложненной тотальным гнойным медиастинитом / В. И. Гаштов, С. В. Мовергоз, А. В. Якушев [и др.] // Успехи современного естествознания. - 2009. - № 9. - С. 43-45.

5. Хирургическое лечение гнилостной флегмоны шеи / В. И. Десятерик, Ю. М. Кривицкий, А. А. Светловский [и др.] // Клінічна хірургія. - 1998. - № 3. - С. 27-28.

6. Тотальный одонтогенный медиастинит как осложнение гнилостно-некротической флегмоны дна полости рта / И. М. Юлдашев, Б. К. Ургуналиев, А. А. Ашиналиев [и др.] // Тихоокеанский медицинский журнал. - 2011. - № 3. - С. 97-98.

7. Cervical necrotizing fasciitis / G. Dimofte, G. Lozneanu, D. Piep- tu [et al.] // Jurnalul de Chirurgie. - 2009. - № 5. - P. 182-186. 8. Морозова М. Н. Шкалы оценки тяжести состояния пациентов с одонтогенными флегмонами / М. Н. Морозова // Вісник проблем біології і медицини. - 2014. - № 4. - С. 341-345. 9. An algorithm for early diagnosis of cervicofacial necrotising fasciitis / V. Malik, C. Gadepalli, S. Agrawal [et al.] // European Archives of Oto-Rhino-Laryngology - Springer. - 2010. № 267. - P. 1169-1177.

10. Lee J. W. Techniques for early diagnosis and management of cervicofacial necrotizing fasciitis / J. W. Lee, S. B. Immerman, L. G. Morris // The Journal of Laryngology \& Otology. 2010. - № 7. - P. 759-764.

\section{REFERENS}

1. Shaariyah, M.M., Marina, M.B., \& Razif, M.Y. (2010). Necrotizing fasciitis of the head and neck: surgical outcomes in three cases. Malaysian Journal of Medical Sciences, 2, 51-55.

2. Farmahan, S., Tuopar, D., \& Ameerally, P.J. (2014). Microbiological examination and antibiotic sensitivity of infections in the head and neck. Has anything changed? British Journal of Oral and Maxillofacial Surgery, 7, 632-635.

3. Thomas, A.J. (2012). Retrospective evaluation of laboratorybased diagnostic tools for cervical necrotising fasciitis. The Laryngoscope, 122, 2683-2687.

4. Gashtov, V.I., Movergoz, S.V., \& Yakushev, A.V. (2009). Sluchay uspeshnogo lecheniya odontogennoy gnilostnoy flegmony shei, oslozhnennoy totalnym gnoynym mediastinitom [A case of successful treatment for odontogenic necrotizing neck phlegmon, complicated by total purulent mediastinitis]. Uspekhi sovremennogo estestvoznaniya - Advances in Current Natural Sciences, 9, 43-45 [in Russian].

5. Desyaterik, V.I., Krivitskiy, Yu.M., \& Svetlovskiy, A.A. (1998). Hirurgicheskoe lechenie gnilostnoy flegmony shei [Surgical treatment of necrotizing neck phlegmon]. Klinichna khi-

rurgiya - Clinical Surgery, 3, 27-28 [in Russian].

6. Yuldashev, I.M., Urgunaliev, B.K., \& Ashinaliev, A.A. (2011). Totalnyi odontogennyi mediastinit kak oslozhnenie gnilostno-nekroticheskoy flegmony dna polosti rta [Total odontogenic mediastinitis as complicating disease of Ludwig's angina of mouth]. Tikhookeanskiy meditsinskiy zhurnal - Pacific Medical Journal, 3, 97-98 [in Russian].

7. Dimofte, G., Lozneanu, G., \& Pieptu, D. (2009). Cervical necrotizing fasciitis. Jurnalul de Chirurgie, 5, 182-186.

8. Morozova, M.N. (2014). Shkaly otsenki tyazhesti sostoyaniya patsientov s odontogennymi flegmonami [Scales of estimation of weight of the state of patients in cases of odontogenous]. Visnyk problem biolohii i medytsyny - Journal of Problems of Biology and Medicine, 4, 341-345 [in Russian].

9. Malik, V., Gadepalli, C., \& Agrawal, S. (2010). An algorithm for early diagnosis of cervicofacial necrotizing fasciitis. European Archives of Oto-Rhino-Laryngology, 267, 1169-1177.

10. Lee, J.W., Immerman, S.B., \& Morris, L.G. (2010). Techniques for early diagnosis and management of cervicofacial necrotising fasciitis. The Journal of Laryngology \& Otology, 7, 759-764.

\section{G. SULEIMANOVA ${ }^{1}$, V. O. SHAPRYNSKYI ${ }^{1}$, V. F. KRYVETSKYI ${ }^{1}$, NASR ZAKI NAGEEB, T. A. HMELEVSKA ${ }^{2}$}

M. Pyrohov Vinnytsia National Medical University ${ }^{1}$

M. Pyrohov Vinnytsia Regional Clinical Hospital ${ }^{2}$

\section{TREATMENT OF CERVICAL NECROTIZING FASCIITIS, COMPLICATED BY MEDIASTINITIS, ON PATIENT WITH HYPOERGIC IMMUNE RESPONSE}

\begin{abstract}
The aim of the work: to describe the correct method of treatment of patients with putrefactive neck abscess complicated with mediastinitis on example of case of successful treatment of the patient with complicated cervical necrotizing fasciitis and hypoergic immune response.

Necrotizing fasciitis of the neck complicated by mediastinitis is uncommon disease with high mortality rate (40-85\%). The article presents the successful treatment of patient with progressive cervical necrotizing fasciitis and hypoergic immune response. He suffered from rheumatoid arthritis and took glucocorticosteroids for a long time. Early surgical intervention with maximally wide opening and drainage of all damaged cellular spaces and adequate antibiotic coverage is only true treatment method.
\end{abstract}

Key words: cervical necrotizing fasciitis; mediastinitis; cervicotomy. 


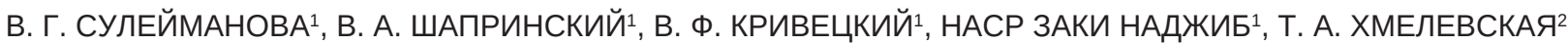

Винницкий национальный медицинский университет им. Н. И. Пирогова ${ }^{1}$

Винницкая областная клиническая больница им. Н. И. Пирогова ${ }^{2}$

\section{ЛЕЧЕНИЕ ГНИ.ЛОСТНОЙ Ф.ЛЕГМОНЫ НЕИ, ОС.ЛОЖНЕННОЙ МЕДИАСТИНИТОМ, У БОЛЬНОГО С ГИПОЭРГИЧЕСКИМ ИММУННЫМ ОТВЕТОМ}

Цель работы: описать правильный метод лечения пациентов с гнилостной флегмоной шеи, осложнённой медиастинитом, на примере случая успешного лечения больного с осложнённым шейным некротизирующим фасциитом и гипоэргичным иммунным ответом.

Гнилостная флегмона шеи, осложненная медиастинитом, - достаточно редкое заболевание с высоким уровнем летальности (45-85 \%). В статье представлен случай успешного лечения больного с осложненным шейным некротизирующим фасциитом и гипоэргическим иммунным ответом на фоне ревматоидного артрита, длительное время леченного глюкокортикоидами. Раннее хирургическое вмешательство с максимально широким вскрытием и сквозным дренированием всех пораженных клетчаточных пространств с адекватной антибактериальной терапией является единственным верным методом лечения таких пациентов.

Ключевые слова: гнилостная флегмона шеи; медиастинит; цервикотомия.

Отримано 09.12.16 